TITLE:

\title{
Study on Physicochemical Properties of Oxygen Gas and Oxides in Molten Salts(Abstract_要 旨)
}

$\operatorname{AUTHOR(S):~}$

Kado, Yuya

\section{CITATION:}

Kado, Yuya. Study on Physicochemical Properties of Oxygen Gas and Oxides in Molten Salts. 京都大学, 2010, 博士(エネルギ一科学)

ISSUE DATE:

2010-03-23

URL:

http://hdl.handle.net/2433/120408

RIGHT: 
( 続紙 1 )

\begin{tabular}{|c|c|c|c|}
\hline 京都大学 & 博士（エネルギー科学） & 氏名 & 加登 裕也 \\
\hline & $\begin{array}{c}\text { Study on Physicochem } \\
\text { Molten Salts（溶融塩 }\end{array}$ & Prope & $\begin{array}{l}\text { ties of Oxygen Gas and Ox } \\
\text { 酸表ガス及で酸化物の物 }\end{array}$ \\
\hline
\end{tabular}

（論文内容の要旨）

本論文は、高温溶融塩中における電気化学的手法を用いた酸化リチウムの溶解度測 定、また新規陽極材料としてボロンドープダイヤモンド (BDD) 電極を用い、酸素発生 電極としての安定性評価及び酸化物イオンに関する熱力学量測定について検討したも のであり、全7章から成り立っている。

第1章は、序論であり、不溶性酸素発生電極を利用したアプリケーションについて 解説し、BDD電極が新規陽極材料として使用できる可能性を説明することにより、本 研究の背景と目的を述べている。また、本論文の内容について総括的に説明してい る。

第2章では、実験に用いた薬品の取扱い、電気化学測定及び分析方法について述べ ている。

第3章では、溶融LiC1-KC1（58.5:41.5，75:25，90:10，100:0 mo1\%)系において、6 73 から 923 Kの温度域で電気化学的手法を用い、酸化リチウムの溶解度を測定した。 作用極にグラッシーカーボン電極を用いてサイクリックボルタンメトリーを行うと、 二酸化炭素ガス発生に起因する酸化電流が観察される。そのピーク電流值は酸化リチ ウムを添加するに従って増大し、飽和すると一定值を示す。そこで、電流值が一定と なった際の添加量を溶解度と決定した。その結果、酸化リチウムの溶解度は温度の上 昇とともに増大することが確認された。また、酸化リチウムの溶解度はLiClを多く含 む系の方が大きくなり、溶融塩の組成依存性が極めて大きいことが判明した。従っ て、溶融塩の組成を調整することによって、比較的低温でも酸化物溶解度の大きい電 解浴が得られることが期待される。さらに、これらの結果をもとに $0_{2} / 0^{2-}$ の標準式量 酸化還元電位を導出したところ、LiClを多く含む電解浴の方がより貴な電位を示すこ とが判明した。

第4章では、大きな酸化リチウム溶解度を持つ $\mathrm{LiCl}$ と $\mathrm{CaCl}_{2}$ をともに含むことから、 比較的低温で大きな酸化リチウム溶解度を持つと期待できる共融組成 $\mathrm{LiCl}-\mathrm{NaCl}-\mathrm{CaCl}_{2}$ に注目し、酸化物イオンの電気化学的挙動について検討を行った。前段階として、77 3 Kにおいて電気化学空を測定し、3.4 Vと決定した。電解後のガス分析からアノード 限界反応は塩素ガス発生、電析物の元素分析からカソード限界反応はLi-Na-Caの合金 析出であることが判明した。また、第3章と同様の方法を用いて、773 Kにおける酸化 リチウムの溶解度は5.2 mol\%であると決定され、比較的低温で酸化リチウムの溶解度 が大きいことが確認できた。次に、BDD電極を用いて、サイクリックボルタンメトリ 一及び定電位電解を行うことによって酸素ガス発生が観察され、赤外分光法から短時 間の電解では二酸化炭素や一酸化炭素は発生していないことを確認した。さらに、X 線回折及び顕微ラマン分光法から電解前後によってダイヤモンド構造が変化しないこ 
とが確認され、不溶性酸素発生電極として使用できる可能性を見出した。

第5章では、BDD電極の酸素発生電極としての安定性を評価した。まず、化学的安定 性を検討するため酸素雾囲気で熱重量測定を行った。870 K 付近から重量減少が観察 され、870 K以下の温度域で酸素発生電極として使用できる可能性が示された。次 に、電気化学的安定性を評価するため、溶融LiCl-KCl（58.5:41.5，75:25 mol\%)、共 融 $\mathrm{LiCl}-\mathrm{CaCl}_{2}(64: 36 \mathrm{~mol} \%)$ 及び共融 $\mathrm{LiCl}-\mathrm{NaCl}^{-} \mathrm{CaCl}_{2}$ (52.3:13.5:34.2 mol\%)におい て、定電流電解を行い、電子顕微鏡観察、X線回折及び顕微ラマン分光測定によって 表面分析を行った。その結果、BDD電極は 773 K以下の溶融LiC1-KC1中で酸素発生電極 として安定に動作することが判明した。また、電極の安定性は、酸化物イオン濃度及 びLiCl-KC1の組成には依存しないことが示唆された。一方で、溶融LiCl-CaCl 2 及びLiC 1-NaCl-CaCl${ }_{2}$ 中では長時間電解によって電極の消耗が確認され、BDD電極はLiCl-KCl系 における方がより安定であることが確認された。この理由として、 $\mathrm{CaCl}_{2}$ を含む電解浴 では酸素発生過電圧が大きいことが考えられる。これらの結果から、BDD電極の高い 安定性及び酸化リチウムの大きな溶解度を考慮すると、BDD電極を対極に用いた金属 酸化物の電解還元プロセスには、溶融LiCl-KCl（75:25 mol\%）が最も適切な電解質の 候補であることが分かった。

第6章では、溶融LiC1-KC1 (58.5:41.5，65:35，70:30，75:25 mol\%)系においてBDD 電極を用いて酸素電極反応について熱力学的検討を行った。まず、 $0.5 \mathrm{mo}$ \%の酸化り チウムを含む共融LiC1-KC1（58.5:41.5 mol\%）において種々の酸素圧に対する起電力 を測定したところ、酸素厓の対数に対して直線的に変化し、その傾きから反応電子数 が1.91 と計算された。同様にして、0.5 atmの酸素雾囲気中における種々の酸化物イ オン濃度に対する起電力測定から反応電子数は 2.03 と計算された。これらの結果か

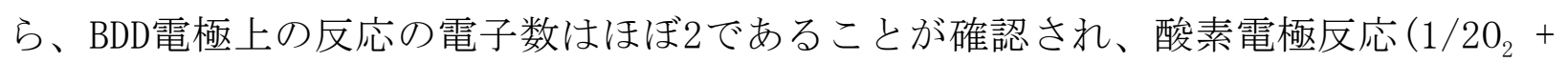
$\left.2 \mathrm{e}^{-}=0^{2-}\right)$ を正確に観察できることが判明した。他の組成でも同様に測定を行い、 $\mathrm{O}_{2} / \mathrm{O}^{2-}$ の標準式量酸化還元電位を導出した結果、第3章の結果と同様にLiClを多く含む電解 浴の方がより貴な電位となることが確認された。白金電極を用いた過去の報告では混 成電位を観察している可能性が大きいため、BDD電極によってより正確に測定できた と考えられる。また、溶融塩中における $\mathrm{Li}_{2} 0$ の生成自由エネルギー変化、エントロピ 一変化及びエンタルピー変化を計算し、 LiC1のモル分率1まで外挿することによっ て、 $\mathrm{LiCl}$ 単塩における熱力学量を導出した。さらに、酸化物イオンの活量係数を導出 したところ、LiClを多く含む方が活量係数は小さくなることが判明した。

第7章は、結論であり、本論文で得られた成果および今後の展望について要約して いる。 


\section{（論文審査の結果の要旨）}

本論文では、高温溶融塩中における酸化リチウムの溶解度を電気化学的手法によ り測定し、不溶性酸素発生電極の新規材料としてボロンドープダイヤモンド (BDD) 電 極を用い、安定性及び酸化物イオンに関する熱力学量の検討により得られた有用な 知見をまとめたものであり、主な結果は以下の通りである。

溶融LiCl-KCl (58.5:41.5，75:25，90:10，100:0 mo1\%)系において、673-923 Kの 温度域で酸化リチウムの溶解度を測定し、溶解度は温度の上昇とともに増大するこ と、 LiClを多く含む系の方が溶解度が大きいことを明らかにしている。さらに、そ れらの結果をもとに $0_{2} / 0^{2-}$ の標準式量酸化還元電位を導出している。

$773 \mathrm{~K}$ の共融組成 $\mathrm{LiCl}-\mathrm{NaCl}-\mathrm{CaCl}_{2}$ に注目し、電気化学空は3.4 V、酸化リチウムの 溶解度は5. 2 mol\%であるとことを確認し、比較的低温で酸化リチウムの溶解度が大 きいことを明らかにしている。また、BDD電極上で酸素ガス発生を確認し、不溶性酸 素発生電極として使用できる可能性を見出している。

長時間の定電流電解試験により、BDD電極は、773 K以下の溶融LiC1-KC1系におい て、酸化物イオン濃度及び電解浴組成にかかわらず酸素発生電極として安定に動作 することを確認している。一方で、溶融 $\mathrm{LiCl}-\mathrm{CaCl}_{2}$ 及び $\mathrm{LiCl}-\mathrm{NaCl}-\mathrm{CaCl}_{2}$ 中では長時 間電解によって電極が消耗し、酸素発生電極としての安定性が電解浴構成イオン、 特にCa ${ }^{2+} イ$ オ、に大きく依存することを明らかにしている。これらの結果から、B DD電極を対極に用いた金属酸化物の電解還元プロセスには溶融LiCl-KCl (75:25 mo1 \%)が最も適切な電解質の一つであると提案している。

溶融LiCl-KCl (58.5:41.5，65:35，70:30，75:25 mo1\%)系において、BDD電極上の 酸素電極反応について熱力学的検討を行い、 $\mathrm{O}_{2} / \mathrm{O}^{2-}$ の標準式量酸化還元電位、酸化物 イオンの活量係数などの熱力学量を導出している。

以上、これらの酸素ガス及び酸化物イオンに関する検討は、酸化物イオンの関わ る溶融塩電気化学プロセスへの応用が期待される内容であり、これまで不十分であ った酸化物イオンに関する熱力学量をより正確に測定しているため、学術的にも工 業的にも非常に有意義なものである。これらの成果をまとめた本論文は、博士学位 論文の水準を十分満たしていると判断し、博士の学位審査の請求に值すると認め る。また、修了に必要な単位を修得済みであることを確認した。よって、本論文は 博士 (エネルギー科学) の学位論文として価值あるものと認める。また、平成22年1月 27日に実施した論文内容とそれに関連した試問の結果合格と認めた。

論文内容の要旨及び審査の結果の要旨は、本学学術情報リポジトリに掲載し、公表と する。特許申請、雑誌掲載等の関係により、学位授与後即日公表することに支障がある 場合は、以下に公表可能とする日付を記入すること。

要旨公開可能日： 年 月 日以降 